\title{
Persepsi Peternak Terhadap Aspek Reproduksi Ternak Kambing di Kabupaten Lombok Utara
}

\section{(Farmers Perception on Goat Reproductionin North Lombok Regency)}

\author{
Lalu Ahmad Zaenuri ${ }^{1 *}$ dan Rodiah ${ }^{2}$ \\ ${ }^{1,2}$ Laboratorium Reproduksi Ternak, Fakultas Peternakan, Universitas Mataram, \\ Jl. Majapahit 62 Mataram 83114, Nusa Tenggara Barat, Indonesia \\ *HP: 081805205702, E-mail: ahmadzaenuri@unram.ac.id
}

Manuscript received: 21-02-2018. Accepted: 09-04-2018

\begin{abstract}
ABSTRAK
Penelitian bertujuan untuk mengetahui persepsi peternak terhadap aspek reproduksi kambing di kabupaten Lombok Utara.Kelompok peternak ditentukan secara purposive random sampling. Setiap kelompok diwakili 10 orang responden. Data ditabulasi dan dikuantifikasi, dihitung nilai rataratanya kemudian diinterpretasi dan dipresentasikan secara deskriptif. Hasil penelitian, dari jumlah populasi awal 5.6 tahun yang lalu sebanyak 243 ekor (50 jantan and 193 betina) tersisa 458 ekor (340 betina dan 118 ekor jantan) berbagai umur, tidak termasuk yang sudah dijual. Responden yang tahu umur kambing kawin pertama berjumlah $80 \%$ dan $88.8 \%$ mengetahui tanda-tanda birahi ternaknya. Responden yang tidak tahu jarak antara beranak dengan birahi berikutnyaberjumlah $67 \%$ dan $37 \%$ menyatakan tahun. Semua responden menyatakan perkawinan kambing dilakukan secara alami.Frekuensi perkawinan untuk menghasilkan kebuntingan 1-2 kali (50\%), 3-4 kali (12\%) dan sisanya $38 \%$ menyatakan tidak tahu. Hanya $56.7 \%$ responden mengetahui lama bunting kambing. Induk yang beranak kembar dua atau lebih 59.3\% dan beranak tunggal $40.70 \%$. Hampir $100 \%$ responden mengetahui ciri-ciri pejantan dan induk unggul dengan persepsi yang berbeda-beda. Disimpulkan, walaupun pengetahuan peternak responden mengenai aspek reproduksi relatif masih kurang tetapi reproduktifitas ternak kambing relatif cukup tinggikarena perkawinan kambing dilakukan secara alami. Untuk mempercepat peningkatan produktivitas kambing yang ada di Kabupaten Lombok Utara, disarankan supaya kambing lokal yang mereka pelihara saat ini disilangkan dengan kambing unggul seperti kambing Ettawa atau kambing Boer.
\end{abstract}

Kata kunci: Survey, peternak, populasi, open days, birahi

\begin{abstract}
The research conducted in order to know farmer perception on goat reproduction in North Lombok District. Farmer groups were selected by purposive random sampling. Each group represented by 10 respondents. Collected data then tabulated and quantified, interpreted and presented descriptively. The initial populations in the past 5.6 years were 243 (50 males and 193 females), currently remaining 458 (340 females and 118 males) excluding those weresold. $80 \%$ of respondents know the age of doe's at the first mating and $88.8 \%$ know oestrus signs. $67 \%$ of respondents did not know post kidding open days. $100 \%$ doe's were naturally mated. $50 \%$ respondents stated mating frequenciesfor optimum fertility rate was 1-2 times, $12 \%$ said 3-4 times and the remaining $38 \%$ did
\end{abstract}


not know. Only $56.7 \%$ of respondents knew doe'slength ofpregnancy. Doe's with twins of two or morekidding were $59.3 \%$ and single kid was $40.70 \%$. Almost $100 \%$ of respondents know genetically superior bucks. In conclusion, on one hand the perception of respondent's on goat reproduction is relatively low, but on the other hand the goat production was relatively high. To accelerate the increase in productivity of goats in North Lombok Regency, was recommended that local goats are crossed with superior goats such as Ettawa goats or Boer goats.

Key words: Survey, farmers population, open days, oestrus

\section{PENDAHULUAN}

Kambing adalah ternak yang sudah sangat merakyat dan populer di hampir seluruh Indonesia terutama di daerah pedesaan.Daya adaptasinya sudah teruji selama ratusan tahun sehingga kambing, khususnya kambing kacang, dapat dikatakan sebagai kambing asli Indonesia. Walaupun demikian, produktifitas ternak kambing harus selalu ditingkatkan secara nyata tidak hanya untuk meningkatkan pendapatan peternak tetapi juga untuk memenuhi permintaan yang selalu meningkat dari waktu ke waktu. Ada tiga alas an utama perlunya peningkatan produktifitas kambing di Indonesia maupun di Nusa Tenggara Barat.

Pertama, sejak tahun 1999 FAO sudah memprediksi akan terjadi perubahan signifikan pada sektor peternakan dunia yaitu ketika konsumsi daging dunia meningkat $2.9 \%$, di negaranegara berkembang sudah melajusampai 5.4\%, bahkan di Asia Tenggara mencapai 5.6\%, sementara di negara-negara maju meningkat hanya 1\%. Kedua, sampai tahun 2020 diperkirakan pertumbuhan konsumsi daging di negara berkembang rata-rata $2.8 \%$ per tahun, sementara di negara-negara maju hanya $0.6 \%$ per tahun (FAO, IFAD and WFP, 2015). Kedua, data tersebut menggambarkan, sub sektor peternakan termasuk ternak kambing berpeluang lebih banyak dalam menyediakan daging untuk memenuhi kebutuhan dalam negeri. Terakhir, di Nusa Tenggara Barat, populasi kambing adalah tertinggi kedua setelah sapi. Demikian juga di kabupaten Lombok Utara yaitu berturut-turut 76.086 ekor sapidan28.208 ekor kambing. Populasi kambing tertinggi di kecamatan Bayan (13.036) dan kemudiankecamatan Kayangan, Gangga, Tanjung dan Pemenang yaitu berturut-turut 7.374, 3.900, 2.294, dan 1.604 ekor (Dinas Pertanian, Perkebunan, Kehutanan, Kelautan dan Perikanan Kabupaten Lombok Utara, 2013).

Untuk mengetahui prospek ternak kambing dalam memenuhi kebutuhan masyarakat akan daging, salah satu indikatornya adalah tingkat reproduktifitasnya. Untuk meningkatkan produktifitasnya perlu dilakukan kajian persepsi peternak kambing terhadap aspek reproduksi untuk menjadi dasar justifikasi penyusunan perencanaan pengembangan peternakan kambing di kabupaten Lombok Utara.

Tujuan penelitian ini adalah untuk mengetahuipersepsi peternak terhadap berbagai aspek reproduksi meliputi sistim perkawinan, estrus post partum, lama bunting, jarak beranak, prolifikasi dan produktifitas ternak kambingdi kabupaten Lombok Utara. Hasil kajian ini akan memberikan manfaat antara lain terdokumentasinya menejemen, potensi produksi dan reproduksi yang pada akhirnya akan menjadi bahan rujukan bagi praktisi maupun pemangku kebijakan dalam merencanakan pengembangan ternak kambing di kabupaten Lombok Utara. Dengan tata laksana peternakan kambing yang lebih baik maka peran kambing dalam mensubstitusi sebagian peran sapi untuk menyediakan daging akan meningkat dan pada akhirnya juga akan meningkatkan pendapatan peternak. 


\section{BAHAN DAN METODE}

Penelitian dilakukan dengan metode survey melalui indeep interview dengan peternak kambing dengan tujuan memperoleh data dan informasi secara mendalam dan lengkap tentang subyek kajian, yaitu ternak kambing yang dipelihara oleh peternak yang tergabung dalam beberapa kelompok peternak kambing di kabupaten Lombok Utara.

Kelompok sampel dipilih secarapurposive random sampling berdasarkan karakteristik tertentu seperti populasi, ketinggian tempat, jumlah kelompok peternak kambing, tipe lahan pertanian dan jumlah peternak (Arikunto, 2002). Untuk penelitian ini, dari 5 kecamatan diambil tiga kecamatan dengan populasi ternak kambing tertinggi yaitu Kecamatan Bayan, Gangga dan Kayangan. Dari setiap kecamatan diambil dua kelompok peternak kambing dan setiap kelompok diwakili oleh 10 orang peternak responden.

Data yang dikumpulkan meliputi data kuantitatif dan data kualitatif. Data kuantitatif terdiri dari struktur populasi, umur, paritas, litter size, jenis kelamin anak, estrus post partum, lama bunting dan sistim perkawinan. Data kualitatif meliputi persepsi peternak terhadap aspek-aspek yang berkaitan reproduksi ternak kambing melalui wawancara dan diskusi mendalam dengan peternak meliputi persepsi peternak terhadap induk dan pejantan yang unggul, cara perkawinan yang efisien, tanda birahi dan umur pertama kali dikawinkan. Data ditabulasi dan dikuantifikasi, dihitung nilai rata-ratanya kemudian diinterpretasi dan dipresentasikan secara deskriptif, dibandingkan dengan hasil penelitian terdahulu dan diperkuat oleh argumentasi, landasan teori dan referensi yang relefan dengan topik bahasan.

\section{HASIL DAN PEMBAHASAN}

\section{Latar Belakang Responden}

Identitas responden dipresentasikan pada Tabel 1. Jenis kelamin responden hampir seluruhnya laki-laki (99\%), rata-rata umur dan pengalaman beternak 39.4 dan 13.2 tahun, kambing yang mereka miliki saat ini sudah dipelihara selama 5.6 tahun. Pendidikansebangian besar SD (43.3\%), diikuti SMP, buta Huruf dan SMA berturut-turut 21.7\%, 20\%, dan 13.3\%.

Tabel 1. Identitas responden

\begin{tabular}{|c|c|c|c|c|c|c|c|c|}
\hline No & Keterangan & $\mathrm{L}$ & $\mathrm{P}$ & Th & $\mathrm{BH}$ & SD & SMP & SMA \\
\hline 1 & Jenis kelamin $(\%)$ & 95 & 5 & & & & & \\
\hline 2 & Umur & & & 39.4 & & & & \\
\hline 3 & Pendidikan & & & & 20 & 43.3 & 21.7 & 15.0 \\
\hline 4 & Pengalaman beternak kambing & & & 13.2 & & & & \\
\hline 5 & $\begin{array}{l}\text { Lama memelihara ternak yang } \\
\text { dimiliki sekarang }\end{array}$ & & & 5.6 & & & & \\
\hline
\end{tabular}

Sumber: Data Hasil Survey 2017

Data pada Tabel 1 menggambarkan, kambing dipelihara oleh semua golongan masyarakat tanpa membedakan umur, pendidikan dan pengalaman beternak. Dengan memelihara, mengembangbiakkan dan mengoptimalkan produktifitas ternak kambing akan meningkatkan peluang ternak kambing mensubstitusi sebagian peran sapi menyediakan daging untuk kebutuhan lokal maupun nasional sehingga, secara tidak langsung akan membantu mempercepat peningkatkan populasi sapi. Sodik (2005) menjelaskan, ternak kambing adalah ternak ruminansia kecil yang sangat potensial untuk dikembang biakkan, 
memiliki kemampuan adaptasi yang sangat tinggi terhadap berbagai lingkungan termasuk di wilayah dengan sumber pakan terbatas, sangat efisien mengubah pakan berkualitas rendah menjadi air susu dan daging, reproduktifitasnya tinggi dan tahan terhadap penyakit, sehingga banyak petani peternak di pedesaan beternak kambing.

\section{Perkembangbiakan Ternak Kambing}

Populasi awal berjumlah 243 ekor yang terdiri dari 50 ekor jantan dan 193 ekor betina berbagai umur. Populasi yang tersisa saat ini adalah 456 ekor yang terdiri dari 340 betina dan 118 ekor jantan berbagai umur, sementara yang sudah dijual tidak terdata oleh peternak (Tabel 2). Sisa populasi tersebut masih tergolong realistis karena kambing termasuk ternak yang sangat prolifik dengan ciri multipel ovulasi dan polytocus, beranak dua kali setahun atau minimal 3 kali dua tahun sehingga bisa berkembang biak dengan sangat cepat. Dijelaskan oleh Devendra dan McLeroy (1982) dan Armijo et al. (2011) bahwa, kambing akan mencapai dewasa kelamin pada umur 4-9 bulan atau rata-rata 8 bulan dan akan memberikan produktifitas yang baik jika mulai dikawinkan pada umur 15-19 bulan, lama bunting 150-154 hari dengan frekuensi beranak rata-rata 3 kali dalam dua tahun.Oleh karena itu, proyeksi perkembangan populasi kambing yang jumlah awalnya 193 ekor induk dan dipelihara selama 5.6 tahun dengan koefisien teknis tiga kali beranak per 2 tahun, 1.5 ekor anak sekelahiran dan angka kematian 20\%, maka dalam waktu 5 tahun akan berkembang menjadi 1.008 ekor jantan betina berbagai tingkatan umur.

Tabel 2.Komposisi Ternak kambing

\begin{tabular}{|c|c|c|c|c|c|c|c|c|c|c|c|c|c|c|c|}
\hline \multirow{2}{*}{\multicolumn{2}{|c|}{ Jumlah awal }} & \multicolumn{14}{|c|}{ Jumlah dan komposisi ternak } \\
\hline & & \multicolumn{3}{|c|}{ Induk (Paritas) } & \multicolumn{4}{|c|}{$\begin{array}{l}\text { Betina muda dan } \\
\text { anak (Bulan) }\end{array}$} & \multicolumn{3}{|c|}{$\begin{array}{l}\text { Pejantan } \\
\text { (Tahun) }\end{array}$} & \multicolumn{4}{|c|}{ Pejantan muda (Bulan) } \\
\hline Jtn & Btn & 1 & 2 & 3 & $3>$ & $4>$ & 12 & $6-11$ & $1-5$ & 2 & 3 & $3>$ & 12 & $6-11$ & $1-5$ \\
\hline 50 & 193 & 12 & 52 & 15 & 16 & 133 & 8 & 45 & 59 & 20 & 15 & 19 & 8 & 19 & 37 \\
\hline \multirow{2}{*}{ Total } & \multirow{2}{*}{243} & & 228 & & \multicolumn{4}{|c|}{112} & \multicolumn{3}{|c|}{54} & \multicolumn{4}{|c|}{64} \\
\hline & & \multicolumn{14}{|c|}{458} \\
\hline Rata $^{2}$ & 4,1 & \multicolumn{14}{|c|}{7,6} \\
\hline
\end{tabular}

Sumber: Data Hasil Survey 2017

\section{Status dan Jumlah Kepemilikan}

Hasil penelitian ini mendapatkan, asal usul ternak yang dipelihara oleh peternak responden terdiri dari tiga macam. Pertama, 50\% responden menyatakan, kambing yang mereka pelihara adalah milik sendiri, $33.3 \%$ berasal dari bantuan pihak lain (termasuk pemerintah) dan $8.3 \%$ berasal dari peternak lain dengan sistim bagi hasil. Peternak kambing dengan sistim bagi diprediksi bahwa dalam waktu yang tidak terlalu lama akan memiliki ternak kambing sendiri dari hasil pembagian anaknya. Sementara 33.3\% yang pada awalnya berasal dari bantuan dengan sistim bagi hasil, saat ini seluruh responden sudah memiliki kambing sendiri.

Jumlah kepemilikan kambing pada awal mulai beternak sekitar 5.6 tahun yang lalu rata-rata 4.1 ekor per peternak. Saat ini jumlah kepemilikan per peternak sudah meningkat menjadi 7.6 ekor per peternakatau relatif cukup berpengaruh terhadap struktur pendapatan keluarga petani di KLU. Soekardono et al. (2016) menyatakan, jumlah ternak kambing yang dipelihara pada usaha peternakan kambing skala keluarga baru dapat memberikan kontribusi 
yang signifikan dalam struktur pendapatan rumah tangga petani adalah 1 ST atau 6 ekor induk dan 1 ekor pejantan.Zulfanita (2011) melaporkan, usaha beternak kambing cukup menguntungkan dimana dengan biaya investasi Rp. 18,337,000 diperoleh pendapatan ratarata sebesar Rp. 2,888,000 per bulan.

Tabel 3.Status ternak dan model kandang

\begin{tabular}{clcc}
\hline No & \multicolumn{1}{c}{ Keterangan } & Jumlah (orang) & Persentase \\
\hline 1 & Asal ternak & 35 & \\
& a. Milik Sendiri & 5 & 58.3 \\
& b. Bagi hasil & 20 & 8.3 \\
& c. Bantuan pihak lain & & 33.3 \\
& Perjanjian kerjasama untuk b dan c & 8 & 33 \\
& Ada & 17 & 67 \\
& Tidak ada & & \\
Model kandang & 20 & 34 \\
& a. Kandang panggung & 0 & 0 \\
& b. Kandang baterey & 40 & 65 \\
& c. Lantai tanah & 0 & 0 \\
\hline
\end{tabular}

Sumber: Data Hasil Survey 2017

Skala usaha adalah faktor yang sangat penting sebagai bahan pertimbangan untuk mencapai tujuan produksi sesuai dengan sumber daya petani peternak (Setiadi et al., 2001). Pada umumnya, usaha peternakan kambing di pedesaan masih berskala kecil sehingga petanipeternak belum mengalokasikan waktu dan tenaga kerja keluarga yang terlibat secara optimal sehingga, hasil yang diperoleh relatif sedikit karena hanya merupakan usaha sambilan.

\section{Pengetahuan Peternak Terhadap Aspek Reproduksi}

Sebagian besar responden (80\%) mengetahui umur ternaknya pada saat kawin pertama. Demikian juga peternak yang mengetahui tanda-tanda birahi ternaknya dinyatakan oleh sebagian besar responden (88.8\%). Sebaliknya, peternak yang tidak tahu umur ternak kambing kawin pertama kali dan tanda-tanda birahi pada ternak kambing dinyatakan oleh sebagian kecil responden yaitu $20 \%$ vs $11.2 \%$ (Tabel 4).

Pengetahuan mengenai umur kawin pertama dan tanda-tanda birahi pada ternak sangat penting diketahui oleh peternak. Jika ternak kambing terlambat dikawinkan karena peternak tidak tahu ternaknya dalam keadaan birahi, maka kerugian akan dialami selama satu siklus yaitu 19-21 hari berupa waktu, tenaga kerja, biaya pakan dan kesempatan untuk mendapatkan anak kambing sesuai kapasitas alamiahnya. Jika keterlambatannya dua siklus estrus atau lebih, maka kerugiannya akan berbanding lurus sesuai jumlah siklus yang terlewati.

Prolifikasi dan produktifitas ternak kambing tidak hanya ditentukan oleh ternak tetapi juga peternaknya sendiri. Tabel 4 menampilkan, sebagian besar peternak (80\%) tahu perkiraan umur ternaknya pada waktu kawin pertama walaupun persepsinya terhadap umur kambing kawin pertama berbeda-beda. Umur kawin pertama kurang dari 1 tahun dinyatakan oleh $25 \%$, diikuti $0 \%, 25 \%$, dan $6.7 \%$ berturut-turut menyatakan 1, 1.5, dan 2 tahun.

Persepsi peternak mengenai umur kawin pertama seperti dijelaskan diatas menunjukkan bahwa peternak sudah menerapkan manajemen reproduksi relatif cukup baik. Walaupun 
kambing betina sudahmencapai dewasa kelamin pada umur 6-8 bulan tetapi, jika dikawinkan sebelum mencapai dewasa tubuh akan menimbulkan beberapa dampak negatif jika tidak diimbangi dengan kuantitas dan kualitas pakan yang cukup karena,induk muda masih membutuhkan nutrisi untuk dirinya serta fetus yang dikandungnya. Jika kualitas pakannya rendah kemungkinan terjadinya aborsi sangat tinggi serta umur produktif ternak akan menjadi lebih pendek.

Tabel 4. Umur kawin pertama dan tanda birahi ternak kambing

\begin{tabular}{rlcc}
\hline No & Keterangan & Jumlah & $\%$ \\
\hline 1 Umur kawin I (Tahun) & & \\
& 1.Tidak tahu & 12 & 20 \\
& 2.Tahu yaitu & 48 & 80 \\
& a. Kurang 1 tahun & 12 & 25 \\
& b. 1 tahun & 16 & 33 \\
& c. 1,5 tahun & 15 & 31 \\
d. 2 tahun & 5 & 11 \\
\hline Tanda birahi induk kambing & 7 & \\
1.Tidak tahu & 53 & 11.7 \\
2.Tahu yaitu & 25 & 41.7 \\
a. Menaiki temannya & 12 & 47 \\
b. Mengeluarkan suara khas & 2 & 23 \\
& c. Keluar cairan dari vulva & 13 & 4 \\
d. Menggosok bandan di kandang & & 25 \\
\hline
\end{tabular}

Sumber. Data hasil survey 2017

Menurut Devendra dan Burns (1994), priode perkawinan dapat dihitung dengan cara mengurangi interval beranak dengan lama bunting sehingga priode perkawinan pertama merupakan selisih umur beranak pertama dengan perkawinan pertama, dan dikurangi lama bunting. Priode perkawinan pertama pada kambing Kacang adalah 36.25 hari sedangkan hasil silang kambing Boer dan kambing kacang adalah 57.52 hari.Artinya untuk mencapai kebuntingan kambing Kacang dan Boer cross membutuhkan waktu selama 36.25 hari dan 57.22 hari setelah birahi pertama.

Berdasarkan kisaran periode perkawinan pada kambing kacang dan kambing peranakan Boer, masing-masing mempunyai periode perkawinan yang pendek atau perkawinan pada birahi pertama dapat menghasilkan kebuntingan. Hal ini disebabkan karena umumnya birahi pertama diikuti oleh ovulasi (Sutama et al., 1995). Sedangkan untuk periode perkawinan terpanjang adalah 125 hari pada kambing Kacang dan 117 hari pada kambing peranakan Boer tetapi perkawinan pertama pada kambing sebaiknya ditunda minimal 3 atau 4 siklus setelah birahi pertama untuk memastikan induk kambing benar-benar sudah mencapai dewasa tubuh sehingga masa produktif dan produktifitasnya maksimal (Sugiharso, 2009).

Selain pendekatan dewasa kelamin dan dewasa tubuh, pendekatan berat badan juga perlu dipertimbangkan sebelum membiarkan ternak kawin pada umur yang terlalu muda. Devendra dan Burns (1994) menganjurkan untuk tidak mengawinkan kambing betina muda sampai mereka mencapai berat minimal dua pertiga dari bobot badan dewasa. Sebaiknya, kawin pertama pada kambing Kacang dilakukan ketika bobot badannya 18-20 kg karena berat badan lebih penting dari pada umur dalam menentukan waktu dewasa kelamin dan 
dewasa tubuh. Oleh karena itu ternak yang pertumbuhannya cepat akan mencapai pubertas lebih awal sesuai dengan target weight theory, yaitu seekor ternak akan mencapai pubertas dan aktivitas produksi dapat berlangsung secara normal jika telah mencapai bobot badan tertentu (Sugiharso, 2009).

Tanda-tanda birahi harus diketahui dengan baik oleh setiap peternak, sehingga tidak terlambat mengawinkan ternaknya.Semakin sering tertunda mengawinkan ternaknya semakin banyak kerugian bagi peternak tetapi kerugian ini biasanya tidak disadari oleh peternak.Hasil penelitian ini mendapatkan, sebagian besar peternak mengetahui ciri-ciri ternaknya yang sedang birahi (Tabel 4). Persepsi responden terhadap ciri-ciri birahi ternak kambing yang paling umum adalah menaiki temannya, menggosok-gosokkan badannya pada tiang kandang atau pohon atau benda lainnya, keluar lendir atau cairan dari vulvanya serta kambing kelihatan selalu gelisah dan tidak tenang.

Jarak antara beranak dengan birahi berikutnya juga aspek reproduksi yang sangat penting dimana sebagian besar peternak (67\%) menyatakan tidak tahu dan sisanya (37\%) tahu yaitu berkisar antara 30-90 hari. Kisaran jarak beranak dengan birahi berikutnya sesuai dengan persepsi peternak responden dalam penelitian ini yaitu 30-90 hari masih dalam kisaran normal. Ternak kambing yang sehat danpemberian pakan dengan kualitas yang baik akan menunjukkan sifat-sifat reproduksi yang maksimal. Dengan pemeliharaan dan pemberian pakan yang berkualitas, masa involusi uterus yaitu waktu yang dibutuhkan oleh uterus untuk kembali kekondisi sebelum beranak dan memulai aktifitas reproduksinya, akan semakin cepat. Waktu involusi uterus yang termasuk sangat baik adalah antara $14-\leq 40$ hari. Jika involusi uterus kurang lebih 40 hari maka ternak kambing akan mampu beranak dua kali setahun. Sementara jika 90 hari, maka induk kambing akan beranak minimal 3 kali setahun. Tetapi jika lebih dari 90 hari, seperti dinyatakanoleh 8 orang responden, maka ternak tersebut tergolong tingkat reproduksi dan produktifitasnya rendah, karena induk kambing tidak akan mampu beranak 3 kali dalam dua tahun.

Tingkat kinerja reproduksi ternak tergantung pada interaksi faktor genetik dan lingkungan, tetapi faktor lingkungan lebih berpengaruh dibanding faktor genetik (Preston dan Leng, 1987). Pada kondisi lingkungan yang sangat minim daya dukung sumber pakan, air minum, suhu terlalu panas dan lainnya, kinerja reproduksi cendrung menurun sehingga fertilitasnya rendah, dewasa kelamin terlambat dan interval beranak lebih lama (Devendra dan Burns, 1994). Walaupun demikian, kambing Kacang memiliki keunggulan komparatif dibanding jenis kambing lainnya yaitu mudah beradaptasi dengan lingkungan setempat dan reproduksinya cukup baik, pada umur 15-18 bulan bisa menghasilkan keturunan dengan litter size rata-rata adalah 1.57 ekor (Setiadi et al., 2001).

Sistim perkawinan sangat menentukan kinerja reproduksi ternak.Perkawinan alam menghasilkan kebuntingan jauh lebih tinggi dibanding Inseminasi Buatan. Hasil penelitian ini mendapatkan, $100 \%$ perkawinan kambing dilakukan secara alami, 50\% menyatakan frekuensi perkawinan untuk menghasilkan kebuntingan adalah 1-2 kali dan 12\% lainnya menyatakan 3-4 kali dan sisanya 38\% menyatakan tidak tahu (Tabel 5).

Jika beberapa induk di dalam satu kelompok ternak betina mengalami birahi dalam waktu bersamaan sementara jumlah pejantan sedikit maka tingkat kebuntingan nyata akan menurun. Hal ini disebabkan karena mating load pejantan terlalu tinggi sehingga fertilitasnya menurun. Oleh karena itu, induk yang sedang mengalami puncak estrus cukup dikawinkan 
satu atau dua kali saja untuk menjaga kualitas semen yang dihasilkan pejantan tetap optimal (Zaenuri dan Rodiah, 2003).

Tabel 5. Jarak beranak dengan kawin berikutnya dan sistim perkawinan pada kambing

\begin{tabular}{clcc}
\hline No & \multicolumn{1}{c}{ Keterangan } & Jumlah & $\%$ \\
\hline 1 & Jarak beranak dgn kawin berikutnya & & \\
& a. Tidak Tahu & 40 & 67 \\
& b. Tahu yaitu & 20 & 33 \\
& 1. 30 hari & 3 & 15 \\
2. 60 hari & 5 & 25 \\
3. 90 hari & 6 & 30 \\
4. $90>$ hari & 6 & 30 \\
\hline 2 Sistim perkawinan ternak & & \\
1. Kawin alam & 60 & 100 \\
2. Setelah ada tanda birahi & 0 & 0 \\
3. Frekuensi perkawinan & 0 & 0 \\
a. 1-2 kali & 30 & 50 \\
b. 3-4 kali & 7 & 12 \\
c. Tidak tahu & 23 & 38 \\
\hline
\end{tabular}

Sumber. Data hasil survey 2017

Jarak beranak adalah periode antara dua beranak yang berurutan. Semakin pendek jarak beranak, semakin tinggi produksinya, sedangkan semakin cepat timbulnya estrus setelah beranak mengindikasikan bahwa kambing tersebut memiliki sifat reproduksi yang baik (Devendra dan Burns, 1994). Beberapa peneliti sebelumnya melaporkan,jarak beranak pada induk kambing minimal 205 hari pada kambing Kacang dan maksimum 250 hari pada kambing PE (Sodiq dan Sadewo, 2008). Sedangkan Devendra dan Burns (1994) menyatakan, lama periode perkawinan tergantung seberapa cepat induk bunting lagi setelah beranak, yang pada gilirannya tergantung pada timbulnya kembali siklus berahi. Tetapi kenyataan yang sering ditemukan, kidding Intervalsatu tahun dan kadang-kadang lebih lama(Chaniago, 1993), 8.2 \pm 0.14 bulan untuk kambing Kacang (Elieser et al., 2012), 9.07 \pm 0.6 bulan pada kambing yang digembalakan dan $9.85 \pm 1.7$ bulan pada sistem pemeliharaan yang dikandangkan (Zaenuri dan Rodiah, 2003), karena ternak betina pada saat estrus tidak dikawinkan disebabkan oleh ketidaktahuan peternak mengenai cirri-ciri birahi ternaknya.

Persepsi peternak mengenai jarak antar birahi tergolong sangat minim seperti tercantum pada Tabel 6. Minimnya pengetahuan responden mengenai jarak antar birahi mengakibatkan menurunkan kapasitas reproduksi ternaknya. Jika induk tidak bunting akibat tidak dikawinkan dengan alasan tidak tersedia pejantan, peternak dapat mengawinkan ternaknya pada siklus berikutnya jika mereka ingat atau mencatat tanggal estrus sebelumnya sehingga, peternak dapat memprediksi kapan estrus berikutnya akan terjadi.

Hasil penelitian mengenai lama bunting mendapatkan, hanya 4 orang yang menyatakan tidak tahu, sementara 56 orang yang menyatakan tahu hanya 34 orang yang memberikan jawaban yang benar yaitu sekitar 150 hari, sisanya memberikan jawaban yang tidak sesuai dengan sifat alami ternak kambing (Tabel 6). Rataan lama bunting seperti dilaporkan oleh Adhianto (2012) adalah 159.3 hari. Jika peternak tidak mengetahui lama bunting ternaknya maka, peternak tidak dapat memperkirakan waktu ternaknya akan beranak dan tidak dapat 
mengatur manajemen pakan sesuai umur kebuntingan ternaknya. Trisemester terakhir masa kebuntingan adalah masa yang sangat krusial bagi induk dan fetusnya karena $75 \%$ pertumbuhan fetus terjadi pada periode ini sehingga perlu diberikan pakan yang cukup kuantitas maupun kualitasnya.

Tabel 6. Jarak birahi dengan birahi berikutnya dan lama pada kambing

\begin{tabular}{clcc}
\hline No & Keterangan & Jumlah & $\%$ \\
\hline 1 & Jarak birahi dengan birahi berikutnya & & \\
& a. Tidak Tahu & 24 & 40 \\
& b. Tahu yaitu & 36 & 60 \\
& 1. 21 hari & 8 & 22 \\
& 2. 28 hari & 8 & 22 \\
& 3. 35 hari & 20 & 56 \\
\hline 2 & Lama bunting & & \\
& a. Tidak tahu & 4 & 7 \\
& b. Tahu yaitu & 56 & 93 \\
& 1. 90 hari & 5 & 8.9 \\
& 2. 120 hari & 1 & 1.7 \\
& 3. 150 hari & 34 & 60.7 \\
& 4. 180 hari & 12 & 21.5 \\
5. 180 hari $>$ & 4 & 7.1 \\
\hline
\end{tabular}

Sumber. Data hasil survey 2017

\section{Prolifikasi dan Ciri Fenotipe Bibit Kambing yang Baik}

Hasil penelitian ini mendapatkan, paritas induk sebagian besar 4> (133 ekor) diikuti oleh paritas 2 (52 ekor), lebih dari 3 (16 ekor) dan 3 (15 ekor) dan sisanya paritas 1 (Tabel 2).Dari komposisi induk kambing yang ada saat ini, cukup realistis jika perkembang biakannya relatif cukup cepat dan tercatat bahwa sisa kambing yang ada saat ini sebanyak 458 ekor, dimana sebaran paritas induk juga cukup realistis jika dihubungkan dengan data yang dipresentasikan pada Tabel 7. Sebagian besar induk yang dimiliki oleh responden saat ini (56 ekor) beranak kembar 2, diikuti beranak kembar 3 (8 ekor induk) dan beranak kembar 4 (3 ekor induk) dan sisanya sebanyak 46 ekor beranak tunggal.

Beberapa peneliti sebelumnya melaporkan, rata-rata litter size induk kambing pada kondisi pedesaan adalah1.76 ekor (Knipscheer et al., 1994), 1.62 ekor (Adhianto et al., 2012), 1.54 ekor (Setiadi et al., 2001). Litter size dipengaruhi oleh beberapa faktor yaitu umur dan bobot badan induk, kualitas pejantan, musim dan kualitas pakan yang diberikan sebelum dan selama bunting (Land dan Robinson, 1985).

Pada Tabel 7 dipresentasikan, litter size rata-rata 1.7 ekor dimana persentase jumlah induk yang beranak kembar lebih tinggi (59.3\%) dibandingkan dengan yang beranak tunggal (40.7\%) tetapi lebih rendah dibanding beberapa laporan hasil-hasil penelitian sebelumnya. Pada stasiun percobaan jumlah induk kambing beranak kembar adalah 86.3\% (Knipscheer et al., 1994) dan 78\% pada kondisi pedesaan (Setiadi et al., 1997). Ditambahkan, daya hidup anak kambing dari induk paritas 2 dan 3 lebih tinggi dibanding paritas 1 (Farid dan Fahmi, 1996). Hal ini mungkin disebabkan karena naluri keindukan induk paritas diatas 1 lebih tinggi karena naluri keindukan berhubungan dengan tingkat kedewasaan tubuh yaitu semakin 
bertambah umur induk, mekanisme hormonal organ reproduksi akan berfungsi dengan lebih sempurna.

Tabel 7. Litter size, ciri calon induk, dan calon pejantan yang baik

\begin{tabular}{|c|c|c|c|c|}
\hline \multirow{2}{*}{ No } & \multirow{2}{*}{ Keterangan } & \multicolumn{3}{|c|}{ Jumlah } \\
\hline & & Peternak & Induk & Anak \\
\hline \multirow[t]{7}{*}{1} & Litter size & & & \\
\hline & a. Tunggal & 16 & 46 & 46 \\
\hline & b. Kembar 2 & 33 & 56 & 112 \\
\hline & c. Kembar 3 & 8 & 8 & 24 \\
\hline & d. Kembar 4 & 3 & 3 & 12 \\
\hline & Jumlah & 60 & 113 & 197 \\
\hline & Rata-rata & - & 1,8 & 1,7 \\
\hline \multirow[t]{7}{*}{2} & Ciri calon pejantan yang baik & & & \\
\hline & a. Tidak tahu & 0 & & \\
\hline & b.Tahu yaitu & 60 & & \\
\hline & 1. Sehat, bentuk badan besar & 18 & & \\
\hline & 2. Badan besar telinga panjang & 8 & & \\
\hline & 3. Telinga besar dan panjang & 9 & & \\
\hline & $\begin{array}{l}\text { 4. Telinga panjang kuat kawin kepala hitam } \\
\text { bulu mengkilat, badan besar }\end{array}$ & 25 & & \\
\hline \multirow[t]{7}{*}{3} & Ciri calon induk yang baik & & & \\
\hline & a. Tidak tahu & 4 & & \\
\hline & b.Tahu yaitu & 56 & & \\
\hline & 1. Sehat dan besar & 12 & & \\
\hline & 2. Sehat, badan dan ambing besar & 18 & & \\
\hline & 3. Aambing besar dan cepat beranak & 8 & & \\
\hline & 4. Kepala hitam, bulu mengkilat cepat beranak & 18 & & \\
\hline
\end{tabular}

Sumber. Data hasil survey 2017

Untuk mendapatkan ternak dengan potensi genetik dan produksi yang optimal harus dikenali cici-ciri fenotipenya. Hasil penelitian ini menunjukkan (Tabel 7), semua responden menyatakan tahu ciri-ciri calon pejantan yang baik yaitu telinga panjang, kuat kawin, kepala hitam, bulu halus mengkilat, badan besar dinyatakan oleh sebagian besar responden (40\%), $50 \%$ responden menyatakan pejantan yang baik harus sehat dan bentuk badannya besar dan sisanya selain badannya besar telinganya juga harus panjang (15\%) dan terakhir yang penting telinga harus besar dan panjang (13\%). Walaupun pengetahuan responden mengenai ciri pejantan unggul relatif cukup baik, tetapi pejantan seperti itu tidak banyak dijumpai di lokasi penelitian. Hal ini mungkin disebabkan karena pejantan unggul khususnya kambing PE harganya sangat mahal sementara peternak tidak memiliki cukup modal untuk membelinya

Calon induk yang baik menurut 56 orang (93\%) responden adalah sehat, bentuk badan besar, ambing besar dan cepat beranak, kepala hitam dan bulunya mengkilat (Tabel 7). Persepsi peternak mengenai calon induk yang baik tersebut mencerminkan bahwa pengetahuan peternak responden mengenai calon induk kambing yang baik relatif cukup baik. 


\section{KESIMPULAN}

Pengetahuan peternak responden mengenai berbagai aspek reproduksi seperti estruspost partum, siklus estrus, lama bunting dan jarak beranak relatif masih kurang. Walaupun demikian, reproduktiftas ternak kambing relatif cukup tinggi karena perkawinan dilakukan secara alami sehingga, peluang ternak kambing untuk mensubstitusi sebagian peran sapi dalam menyediakan daging cukup tinggi dan pada akhirnya juga akan meningkatkan pendapatan peternak

Perlu dilakukan kajian sumbangan real ternak kambing terhadap pendapatan petani/peternak. Untuk meningkatkan produktifitas per satuan ternak dapat dilakukan melalui introduksi pejantan unggul seperti kambing PE atau kambing Boer.

\section{Ucapan Terima Kasih}

Terima kasih disampaikan kepada Pemda Kabupaten Lombok Utara CQ. KepalaDinas Dinas Pertanian Perkebunan Kehutanan Kelautan dan Perikanan Kabupten Lombok Utara yang telah membiayai penelitian ini.

\section{DAFTAR PUSTAKA}

Adhianto K., N. Ngadiyono, Kustantinah dan I. G. S. Budisatria. 2012. Lama kebuntingan, litter size, dan bobot lahir kambing Boerawa pada pemeliharaan pedesaan di kecamatan Gisting kabupaten Tanggamus. Jurnal Penelitian Pertanian Terapan, 12(2): 131-136

Arikunto, S. 2002. Prosedur Penelitian Suatu Pendekatan Praktek. PT. Rineka Cipta. Jakarta Armijo, J.F.V., Rojo, R., Salem, A.Z.M., Lopez, D., Tinoco, J.L., Gonzalez, A., Pescador, N., dan Vara I.A.D. 2011. Trace Elements in Sheep and Goats Reproduction: A Review. Tropical and Subtropical Agroecosystems, 14(1):1-13

Chaniago, T.D. 1993. Produksi Kambingdan Domba di Indonesia: Sistem Manajemen. SebelasMaret University Press,Surakarta.

Devandra, C. dan M. Burns. 1994. Produksi Kambing diDaerah Tropis. Penerbit ITB. Bandung.

Devendra, C. and G.B. McLeroy. 1982. Goat Production in The Tropics. In: Payne, W.J.A. (Ed). Intermediate Tropical Agriculture Series. Longman. London and New York.

Dinas Pertanian, Perkebunan, Kehutanan, Kelautan dan Perikanan Kabupaten Lombok Utara. 2013. Laporan Penyelenggaraan Pemerintahan Daerah.

Elieser, S., G.Sumadi, Suparta dan Subandryo. 2012. Kinerja reproduksi induk kambing Boer, Kacang dan Boerka. JITV, 17(2): 100-106.

Farid, A.H. dan M.H. Fahmy. 1996. The East Friesian and other European breeds. In. Fahmy, M.H. (Ed.). Prolific Sheep.CAB. International.

FAO, IFAD and WFP. 2015. The State of Food Insecurity in the World 2015. Meeting the 2015 international hunger targets: taking stock of uneven progress. Rome, FAO.

Knipscheer, H.C., S.H. Webb and A.Muljadi. 1994. Opportunitiesfor Commercialization ofSmall Ruminant Production in Indonesia. In: Devendra, C. (Ed). Proceedings of Symposium Strategic Development for Small Ruminant Productionin Asia and the Pacific. Bali. Indonesia. 
Land, R.B and D.W.Robinson. 1985. Genetics of Reproduction in Sheep. Garden City Press Ltd, Etchworth, Herts. England.

Preston, T. R. and R. A.Leng. 1987. Matching Ruminant Production Systems with Available Resources in the Tropics and Subtropics. Penambul Books. Armidale

Setiadi, B.,M.Subandriyo, M. Artawidjaja, D. Priyanto, D. Yulistiani, T. Sartika, B. Tiesnamurti, K. Diwyanto dan L. Praharani. 2001. Karakterisasi kambing lokal dan upaya mempertahankan keanekaragaman sumberdaya genetik. Kumpulan HasilHasil Penelitian Peternakan APBN Tahun Anggaran 1999/2000. Balai Penelitian Ternak. Puslitbang Peternakan, Bogor. pp. 188214.

Setiadi, B., I.K. Sutama dan I.G.M. Budiarsa. 1997. Efisiensi reproduksi dan produksi kambing PE pada berbagai tatalaksana perkawinaan. JITV, 2(4): 233-236.

Sodiq, A. 2005. Small ruminant: Implication and research strategy for rural poverty reduction. Jurnal Pembangunan Pedesaan, V(1):1-7.

Sodiq, A. 2001.Indeks reproduksi kambing pada sistim pengelolaan berkelompok dan individual di pedesaan.Jurnal Pembangunan Pedesaan,I (3):47-58

Soekardono, Harjono, L. Wirapribadi, D. Kisworo, Asnawi, Irwan.2016. Road Map Pengembangan Kawasan Sapi Potong di Kabupaten Lombok Utara. Laporan Hasil Penelitian. Kerjasama Dinas Peternakan dan Kesehatan Hewan Provinsi Nusa Tenggara Barat dengan Fakultas Peternakan Universitas Mataram.

Sugiharso. 2009. Pusat informasi untuk investasi dan budidaya kambing etawa. http://www. Kambingetawa/org. (16 April 2017).

Sutama, I.K., I.G. M. Budiarsana, H. Sutiyono and A. Priyani. 1995. Productive and reproductive performance of young Etawah-cross does. J. Ilmu Ternak dan Vet, 1(2): 81-85.

Zaenuri, L.A. dan Rodiah. 2003. Efisiensi penggunaan progesteron untuk induksi birahi ternak kambing lokal (Capra sp). Jurnal Ilmu dan Teknologi Peternakan,2(1):149155.

Zulfanita. 2011. Kajian usaha ternak kambig di desa Lubangsampang kecamatan Pituruh kabupaten Purworejo. Mediagro,7(2):61-68. 